\title{
THE CONSISTENCY OF MERGER DECISIONS AT THE SOUTH AFRICAN COMPETITION COMMISSION
}

\author{
SUNÉL GRIMBEEK ${ }^{\dagger}$, STEVEN F. KOCH AND RICHARD J. GRIMBEEK*
}

\begin{abstract}
The South African Competition Commission's merger decisions for FY2002 through FY2009 are analyzed to empirically identify the factors historically influencing prohibition, conditional approval and unconditional approval, as well as the factors historically influencing whether merger applications are deemed non-complex, complex or very complex. The focus of the analysis is on whether or not the historical process has remained consistent through time, and whether or not that process can be obviously linked to the provisions of the 1998 Competition Act. Initial results point to behaviour that is not consistent over the time period considered; however, those inconsistencies are removed, once additional measures of market contestibility, associated with the 1998 Competition Act are included in the analysis. The final results suggest that the Commission is less likely to approve mergers that they link to markets that are less contestable. In addition to protecting competition, the Commission is simultaneously protecting other public interests. Therefore, our research supports the hypothesis that the Commission consistently applies its legislative remit.
\end{abstract}

J.E.L: K21, L40, D78

Date: October 2012.

Key words and phrases. South African Competition Commission, Merger Decisions.

The authors would like to thank the South African Competition Commission for allowing us to use their data for this analysis. The authors would also like to thank Economic Research Southern Africa for financial support of this research. Finally, the authors would alos like to thank anonymous referees for their contributions to improving this research. Any remaining errors are the sole responsibility of the authors. This analysis is based, in part, on Grimbeek (2011) and Grimbeek, Koch \& Grimbeek (2012).

$\dagger$ Department of Economics, University of Pretoria, Private Bag X20, Hatfield 0028, Republic of South Africa.sunelg@compcom.co.za.

¥ Professor and Head, Department of Economics, University of Pretoria, Pretoria, Republic of South Africa; (O) 27-12-420-5285, (F) 27-86-691-2749. steve.koch@up.ac.za.

* Lecturer, Department of Statistics, University of Pretoria, Private Bag X20, Hatfield 0028, Republic of South Africa. jackie.grimbeek@gmail.com. 


\section{INTRODUCTION}

In the past, which was an era of widespread state intervention in economic activity, merger control in developing countries was not a priority, Adhikari \& KnightJohn (2004). More recently, both internal and external to these economies, the need for competition legislation became apparent. Internally, the privatisation of entities operating in sectors believed to be natural monopolies, such as the utilities sector, as well as the adoption of liberalisation policies, highlighted the importance of a framework capable of eliciting the most favourable efficiency and welfare outcomes in relation to both liberalisation and privatisation. Externally, a wave of international mergers, with potentially negative impacts on local market contestability, highlighted the need to develop tools and legislation to deal with increased multinational corporation market power, and the potential for abuse of dominant positions in local markets.

In South Africa, the transition to democracy in 1994 led to fundamental changes in the form and function of the state and the role of regulatory authorities tasked with helping achieve the government's broader economic development objectives. Merger decisions, the focus of this analysis, play an important role in determining the future structure of economic activity, and, therefore, are expected to influence economic development objectives. The passage of the Competition Act in 1998 (Act no. 89) in South Africa, which resulted in the establishment of the Competition Commission and the Competition Tribunal in September of 1999, was an important step in this process. The Act replaced a weak merger review system, under the previous Competition Board, in which firms decided whether or not to bring mergers to the attention of the Board, with one that requires pre-merger notification in mergers that exceed certain thresholds. ${ }^{1}$

The Commission is an independent body that rules on the appropriateness of mergers, and whose decisions can be appealed to the Tribunal, as well as the Competition Appeal Court. The Act follows mainstream European Union (EU) and,

${ }^{1}$ Roberts (2004) provides a brief discussion of some of the assessments made by this board between 1993 and 1997. 
to a lesser extent, United States (US) competition law by prohibiting practices in restraint of trade, whether vertical or horizontal. However, the legislation differs from the processes followed in most developed economies, since it also promotes underlying social and economic objectives to assist in addressing the previously skewed nature of economic activity in the country. The Act explicitly emphasises development and the public interest, linking competition policy with other economic development policies. ${ }^{2}$

The public interest concern has led to some controversy. ${ }^{3}$ Reekie (1999), for example, argues that employment should solely be an objective of macroeconomic policy, and that previous ownership imbalances will be automatically rectified by the removal of socially biased legislation. However, Lewis (2002) notes that public interest and related concerns have been allayed via conditional approval of certain mergers, rather than outright prohibition; many mergers have been conditionally approved, where the conditions are specifically aimed at minimising job losses. ${ }^{4} \mathrm{In}$ addition to employment issues, Black Economic Empowerment (BEE) - an affirmative action program - has also featured in merger hearings. ${ }^{5}$ Also, according to the Act, if a proposed merger is likely to be anti-competitive, the authorities are required to consider the possibility that technology or efficiency gains may offset those anti-competitive effects.

\footnotetext{
2 The stated objectives of the Competition Act of 1998 are: (a) to promote the efficiency, adaptability and development of the economy, (b) to provide consumers with competitive prices and product choices, (c) to promote employment and advance the social and economic welfare of South Africans, (d) to expand opportunities for South African participation in markets and to recognise the role of foreign competition in the Republic, (e) to ensure that small and medium-sized enterprises have an equitable opportunity to participate in the economy, and (f) to promote a greater spread of ownership, in particular, to increase the ownership stakes of historically disadvantaged persons. See the Competition Act no. 89, South Africa, as amended in 2001.

${ }^{3}$ Trade unions are regular participants in the merger evaluation process, especially when employment issues are at stake. However, there has been very little participation by either government departments or consumer groups, Competition Commission and Competition Tribunal (2009).

${ }^{4}$ In case $72 / \mathrm{LM} / \mathrm{Sep} 04$, the Commission placed a cap on the number of retrenchments that could arise from the merger. Also, in case 46/LM/May05, the Commission required the merged entity to fund skills training for retrenched seasonal farm workers.

${ }^{5}$ In case 66/LM/Oct01, the Commission opposed a merger between a struggling BEE firm and a multinational corporation on the grounds that it contravened BEE objectives. However, the Tribunal approved the merger, finding that there was no purpose in preventing the merger to keep a failing firm on life-support merely to satisfy BEE objectives.
} 
Given the broad objectives contained in the Act, as well as fundamental changes in the structure of industry and the regulation of markets, it is worthwhile examining the efficacy with which the Commission is able to execute its requirements. To this end, this research considers the determinants and the consistency of one aspect of the Commission's remit - merger approval - over the period from fiscal year (FY) 2002 through FY2009 using a sample from the population of notified mergers. The analysis also considers the investigation process, to the extent possible, by examining the determinants of merger categorizations. The sample includes 310 observations, weighted to the population of 2277 merger decisions, from which complete data could be captured. Binary regressions of unconditionally approved vs. prohibited and conditionally approved mergers, based on linear probability models, were analysed, as were oredered logit models of the classification of mergers as non-complex, complex and very complex. The results of the analysis find a number of significant determinants of the Commission's decision-making process. Unconditional approval is more likely when there are low barriers to entry into the market, when other countervailing market power exists to mitigate any anti-competitive effects of the merger, and when there is evidence that either the industry or the market is growing or is otherwise very dynamic. On the other hand, mergers are more likely to be either conditionally approved or prohibited when post-merger market shares are larger, there is concern over coordinated effects, and when public interest concerns are raised. These same variables are important determinants of the complexity of ther merger, as classified by the Commission. The results suggest that the Commission is following both the letter and the intent of the Competition Act, as initially published in 1998, amended in 2001.

The rest of the paper is organized as follows. The following section, Section 2, describes the limited literature related to the examination of merger decisions by competition authorities worldwide. Section 3 outlines the data and sampling procedure used to extract the data for this study. Section 4 outlines the empirical methodology used in the analysis. The results of the empirical analysis are 
presented in Section 5. Finally, in Section 6, those results are discussed further, providing links, where possible, to the rest of the literature; possible extensions to this research are also discussed.

\section{Literature RevieW}

In the United States, competition regulation primarily follows the 1890 Sherman Act, although the legislation, the enforcement guidelines and behaviours have changed since then. Posner (1970) provides the impetus to the literature, examining US enforcement cases between 1890 and $1969 .{ }^{6}$ He concludes his analysis with recommendations that antitrust enforcement activities should follow an appropriate economic framework - that enforcement should be focussed on activities that result in the best outcomes for the least cost. ${ }^{7}$ The South African legislation, see footnote 2 , veers slightly from Posner's recommendation, in that it includes objectives that are not explicitly related to the regulation of competition.

More recently, Coate \& McChesney (1992) and Coate (2005) examine mergers and the behaviour of the Federal Trade Commission (FTC). Coate \& McChesney (1992) make use of a sample of 70 horizontal mergers from the US between 1982 and 1986 to examine whether or not the 1982-1984 merger guidelines, which are based on a series of thresholds with respect to the Hischman-Herfindahl Index (HHI), are followed. They find that these simple guidelines are not closely followed by the FTC, suggesting that other factors were at play; only $43 \%$ of the cases were challenged, even though nearly all violated the HHI guidelines. They also find evidence of political effects on decisions, suggesting that merger decisions are not consistent. In South Africa, the same political party has been in office, since 1994; therefore, it is not possible to directly consider political effects in the following analysis.

${ }^{6}$ Kovacic \& Shapiro (2000) present a detailed historical perspective on the shape of, especially, policy and enforcement in the U.S., since the passage of the Sherman Act in 1890.

${ }^{7}$ Posner's (1970) database was later updated and the relationship between enforcement behaviour and the US busincess cylce was again considered by Ghosal \& Gallo (2001). They apply causality tests related to both Granger (1969) and Geweke, Meese \& Dent (1983), finding that enforcement behaviour is countercyclical. 
Coate (2005) analyses the behaviour of the FTC between 1993 and 2003, using data from 124 fully reviewed horizontal cases - 79 were enforced and 45 were closed without further action. He finds that HHI interacted with coordinated interaction concerns, barriers to entry, hot documents, customer complaints, previous anticompetitive behaviour and whether or not there were unilateral effects, to be strongly predictive of enforcement of (challenges to) the merger. When these separate concerns were removed from the regressions, he finds that any evidence of anticompetitve behaviour is predictive of a challenge, but that procompetitive support, although correctly signed, was not predictive - except in one version of the model. His approach provides a nuanced explanation for some of the results in Coate \& McChesney (1992).

Khemani \& Shapiro (1993), on the other hand, examine the consistency and severity of enforcement related to merger policy in Canada, following the 1986 introduction of the Competition Act, while Avalos \& De Hoyos (2008) examine 239 of the 350 merger cases filed between April 1997 and December 2001 that were evaluated by Mexico's Federal Competition Commission. Using data from 75 mergers from June 1986 through July 1989, Khemani \& Shapiro (1993) find that the market share of the acquiring firm was associated with increased enforcement severity, as are barriers to entry, while import competition was associated with reduced enforcement severity. They also find evidence of enforcement differentiation, in the sense that all of the ordered probit cutoffs are significant. They interpret their results as supporting consistent behaviour by the Director of Investigation and Research, who heads the decisions made by the Canadian Bureau of Competition Policy. In the Mexican study, Avalos \& De Hoyos (2008) conisder a three-part decision outcome, whether to: allow the merger, allow the merger with conditions, or block the merger. Their results, which are broadly in line with the previously noted, as well as the subsequently discussed, papers, suggest that the Mexican competition authority is acting consistently, with respect to the legislation. 
Outside of North America, Weir (1992) and Weir (1993) examine data from 77 United Kingdom (UK) mergers applications, submitted between 1974 and 1990. These analyses have particular relevance to our study, as they concern the 1973 Fair Trading Act, which allows for the public interest to be taken into consideration, and the public interest can override economic considerations. Weir (1992) suggests that public interest was not an important factor. However, he did find a bias in favour of mergers, which he interpets as inconsistent behaviour. Using the same data, Weir (1993) focusses on the factors that made it more likely that the Monopoly and Mergers Commission (MMC) expected increased or decreased competition. His results suggest that the MMC considers different evidence, depending on the expected change in competition, which then has effects on their decisions. In other words, although behaviour is broadly consistent, it is nuanced, as was found with respect to the FTC. Davies, Driffield \& Clarke (1999), rather than considering mergers, examine the probability of adverse findings in cases of abuse of monopoly power, drawing on 73 MMC reports from 1973 to 1995 . They find that the market share of the largest firm, exclusivity in pricing or distribution, and a time dummy are consistently the most important determinants in their series of regressions. The significance of the time dummy can be interpreted as inconsistency in behaviour. In the following analysis, we also make use of time dummies to uncover potential inconsistencies in the South African Commission's decisions.

With respect to the EU, Nilssen (1997) analyses the consistency of the Norwegian Competition Authority, following a case study approach, finding inconsistency in the Norwegian Authority's behaviour based on data from the non-life insurance industry, which is a highly concentrated industry that appears to contain a competitive fringe. In addition, Lindsay, Lecchi \& Williams (2003) find that both large market shares and high barriers to entry are important determinants of merger prohibitions in their sample of 245 decisions made between 2000 and 2002. They further find that neither US incorporation nor Nordic country incorporation affect merger decisions. More recently, Bergman, Jakobsson \& Razo (2005) consider a 
sample of 96 phase-two mergers, finding results that are similar to that of Lindsay et al. (2003). ${ }^{8}$ Their analysis is partial, in that it only considers consistency in the second phase, irrespective of the first stage. They find no evidence that political pressure affects merger decisions by the EC, and, therefore, their results suggest consistency in behaviour; however, they note one substantial caveat: as their data is retrospective, it is not possible to control for intra-investigation inconsistency, such as more strict market definitions. ${ }^{9}$ Their concern is true of all retroscpective analyses, including ours.

With respect to merger analysis in South Africa, previous studies include Theron (2001), Smith (2003) and Roberts (2004). Smith's (2003) analysis is based on mergers notified between 1999 and 2003, focussing on public interest considerations. He finds that conventional measures of competition, such as market share, are important merger approval determinants, although public interest considerations are not generally important. However, the Commission is shown to support Black Economic Empowerment within a subsample of large mergers. Our analysis extends Smith (2003) by considering more recent data, as well as a deeper set of control variables. Theron (2001), rather than conducting a detailed empirical investigation, makes use of qualitative analysis, assessing the Competition Tribunal's treatment of five large merger cases. She argues that public interest goals have not conflicted with competition goals, such as efficiency. Our analysis also extends Theron (2001), since both more and newer data are available to us. Roberts (2004) also presents a short case study of the steel industry, as well as describing cases that were prohibited between 1999 and 2003.

The preceding studies provide the basis for this analysis. In the previous studies, the authors examine the consistency of the decisions made by the competition

\footnotetext{
${ }^{8} \mathrm{An}$ interesting extension of this research program is the consideration of stock market effects of merger decisions, as undertaken by Duso, Neven \& Röller (2007) and Röller \& Neven (2002). Both find that approximately $75 \%$ of merger prohibitions correspond to mergers that were considered anti-competitive by the stock market. Such an analysis is beyond the scope of this paper.

${ }^{9}$ Another strand of the literature investigates the potential impacts of competition authority behaviour on markets, and future merger applications. See, for example, Ivaldi \& Verboven (2005), Neven \& Zenger (2008) and Seldeslachts, Clougherty \& Pita Barros (2009). Developing the appropriate counterfactuals is, however, quite complicated in these settings.
} 
authority when dealing with mergers, focussing primarily on potential political and public interest effects that are generally not included in the legislative remit. Our analysis, therefore, differs, because public interest concerns are included in the Commission's remit. The analyses in the literature are primarily based on binary response models, typically logit or probit, where the dependent variable is some version of whether or not a merger is allowed. Independent variables include various measures of market share, as well as other measures of presumed anti-competitive or pro-competitive market characteristics, such as ease of entry. We generally follow the approach in the literature, although we make use of linear probability models, partly due to the complications that arise when dealing with the effect of public interest concerns (see below). However, we are not able to directly include measures of political pressure in the analysis; therefore, year dummies are used to examine potential inconsistencies.

\section{Data And Method}

3.1. Population of Mergers. During the period FY2002-FY2009, April 2002 to March 2010, a total number of 2368 mergers were notified to the Competition Commission and decided upon. ${ }^{10}$ Another set of notified mergers were subsequently withdrawn by the parties, mainly in anticipation of a non-favourable decision of the Commission, and these mergers were not included in the data. Similarly, a final set of potential mergers were not proposed, as the involved parties anticipated a nonfavourable decision. According to the Act, mergers are classified as small (a combined turnover lower than the determined threshold by the Minister), intermediate (a combined post-merger turnover falling between the lower and higher thresholds), or large (a combined post-merger turnover at or above the higher threshold).

\footnotetext{
${ }^{10}$ All intermediate and large mergers, based on either the size of the combined entity or the size of the target firm, are required to be notified to the Commission. Intermediate mergers are decided upon by the Commission, with provision for the parties to appeal Commission decisions to the Competition Tribunal for adjudication. Large mergers are initially considered by the Commission, which makes a recommendation; however, the matter must be referred to the Tribunal for final adjudication. The Tribunals decision on large mergers may then be appealed in the Competition Appeal Court. Small merger notification is voluntary, and the Commission restricts investigations to small mergers it views as being problematic, due to previous contact between the parties, the parties being involved in current investigations by the Commission or those in priority sectors.
} 
At the beginning of FY2002, the Commission began to categorise all notified mergers according to the level of complexity involved in the analysis of the merger's effect on the relevant markets. Therefore, all mergers notified between September 1999 and March 2002 were excluded from the total population. Mergers are categorized as non-complex, complex and very complex. Non-complex, or Phase I, mergers are those expected to have little or no effect on competition. These include mergers where the parties combined post-merger market share is less than $15 \%$, there are no complex control structures and no public interest issues to consider. Complex, or Phase II, mergers involve tie-ups between direct or potential competitors on a horizontal level, or between customers and suppliers on a vertical level, where the merging parties control more than $15 \%$ of the market post-merger. Very complex, or Phase III, mergers are those that are highly likely to result in a substantial lessening of competition in the post-merger market. These mergers mostly involve the leading market participants. Analysis of Phase III mergers often requires the Commission to obtain specific documents and information from the merging parties and affected third parties.

Of the thousands of mergers notified to the Commission since 1999 only a very small proportion (less than 4 percent) have been prohibited or have been approved subject to conditions imposed on the merging parties, which is in line with international benchmarks; see Competition Commission and Competition Tribunal (2009). Between FY2002 and FY2007, the number of merger notifications rose steadily, and this increase took place in a period of economic, primarily trade, liberalisation and economic restructuring in South Africa. Since FY2008, however, there has been a substantial decline in the number of merger notifications received by the Commission. The decrease can be linked to the global economic crisis and subsequent economic slowdown in South Africa. Also, in April 2009, the Commission changed 
the notification thresholds, which also affected the number of notifications. ${ }^{11}$ During the same period, the Commission also adopted a more vigorous approach to monitoring small mergers for possible competition concerns.

More than half, $54 \%$, of the mergers are horizontal in nature, while vertical mergers cover less than $8 \%$ of the mergers. The manufacturing sector has consistently been the most important driver of merger activity, approximately 26 percent of merger notifications, followed by property transactions, approximately 20 percent of the mergers. In third place is the retail and wholesale trade sector, covering 14 percent of transactions, followed by the finance sector, and then the mining and construction sectors; see Competition Commission and Competition Tribunal (2009).

Taking the Commission's merger categorization system as outlined above, the total population available for examination is described in the Targert Population columns of Table 1 . It is clear from the table that very complex cases constitute a very small percentage of the total population of Commission merger decisions. This target population was used as the basis for the sampling methodology, described in the following subsection.

3.2. Sampling Methodology. The total population available for analysis is 2368 mergers notified to the Commission during the period April 2002 to March 2010, although some merger reports were incomplete yielding a final population of $2277 .^{12}$ From these mergers, a sample of 310 mergers was taken. Sampling was based on a retrospective simple random stratified sampling methodology. Stratification was conditioned on the dependent variable, meaning that all of the 81 conditionally approved or prohibited mergers for which complete data was available, out of the

\footnotetext{
${ }^{11}$ Between February 2001 and April 2009, notification was required if the target firm's assets or turnover exceeded R30 million, or the merging parties' combined assets or turnover exceeded R200 million. Under such circumstances, the merger was considered to be intermediate. In 2009, the respective thresholds were raised to R 80 million and R560 million. For large mergers, the pre-2009 thresholds were R100 million and R3.5 billion. After April 2009, those thresholds were raised to R190 million and R6.6 billion, respectively.

${ }^{12}$ Since the Commission does not have an information system, data was collected from each of the merger reports, and this data was collated for the analysis.
} 
population of 91 mergers, were included in the final sample. The sample of approved mergers, on the other hand, was drawn from the population of approved mergers stratified according to a set of factors - Year, Category and Type - which resulted in 101 Year-Category-Type strata. The final sample was drawn to obtain statistical power of $80 \%$ within the analysis. ${ }^{13}$ To provide for possible non-response (unavailable final reports on the Commissions merger database), an oversampling strategy was administered. For a nominal sample of 229 (Decision A), the size of the oversample was $427 .{ }^{14}$

The initial sample sizes for the strata were based on a proportional allocation. This however, resulted in very low sample sizes for the smaller strata and these numbers were then adjusted, resulting in a disproportionate sample ratio. To accommodate this disproportionality, weighting of the realised sample was necessary to reflect the population sizes of the strata, based on the inverse of the inclusion probability. The effectiveness of the sampling strategy is illustrated in Table 1; see, in particular, the columns Sample Population and Sample. Although it is clear that not all samples are perfectly representative, weighting the data to match the underlying population corrects this problem.

\section{Table 1 about here}

3.3. Control Variables. The values of the independent variables for the analysis were gleaned from the final merger reports of the sampled cases. With the exception of market share, all of the variables used in the analysis are dummy variables. Given the nature of the reports, a number of variables had to be subjectively determined. Specifically, reports rarely included a direct statement in agreement with the basic definition of any of the dummy variables, and, therefore, if it was felt the Commission was of the opinion that, for example, entry barriers were high or that there was significant import competition in the relevant market, entry barriers were assumed to be high or import competition was assumed to exist. Unfortunately, it

\footnotetext{
${ }^{13}$ As a general rule of thumb, a sample size with a power of $80 \%$ is accepted as reasonable.

${ }^{14}$ In administering the sample strategy some final merger reports could not be located, resulting in a final sampled population of 2252 cases, which represents 81 different Year-Category-Type strata.
} 
was not possible to decipher either the exact level of entry barriers or the degree of import competition from the report.

In evaluating mergers, the main test that the Act requires is for the competition authorities to determine whether a merger will result in a substantial reduction in market competition, which requires the consideration of a range of factors relating to actual and potential competition in the relevant markets, as set out in Section 12A.2 of the Act. Therefore, we considered: (a) the actual and potential level of import competition in the market; (b) the ease of entry into the market, including tariff and regulatory barriers; (c) the level and trends of concentration, and history of collusion, in the market; (d) the degree of countervailing power in the market; (e) the dynamic characteristics of the market, including growth, innovation and product differentiation; (f) the nature and extent of vertical integration in the market; (g) whether the business or part of the business of a party to the merger or proposed merger has failed or is likely to fail; and (h) whether the merger will result in the removal of an effective competitor.

In addition to the aforementioned factors, we also made provision for the type of merger - conglomerate, horizontal or vertical - the investigation phase - noncomplex, complex or very complex - the merger category - small, intermediate and large - and the fiscal year in which the merger was notified. Furthermore, as discussed in earlier sections, the Act also makes explicit provisions for public interest concerns within the analysis, and, therefore, if these concerns were raised and noted in the report, an indicator for public interest concerns was created. Finally, provision was also made to include a control accounting for concerns over coordinated effects within the industry in which the merger was proposed.

Each of the included variables captures our interpretation, from the reports, of the Commission's expectation of the effect that any particular merger would have on competition, as well as controlling for potential differences in behaviour over the fiscal years being studied. A summary of the control variables is available in Table 2 , and that summary is provided for both unconditionally approved mergers and 
mergers that were either conditionally approved or prohibited. Within the table, we also report whether or not the underlying mean of the independent variable is estimated to be significantly larger in either the unconditionally approved subsample or the conditionally approved/prohibited subsample.

\section{Table 2 about here}

\section{Empirical Methodology}

The outcome variables avaialable in the data are categorical. These variables include merger decisions: approve without conditions, approve with conditions, or prohibit. In addition to merger decisions, the data collection process also provided information on merger phase, either non-complex, complex or very complex, which is also part of the Commission's merger analysis process. Therefore, empirically, data was available for analysing both final merger decisions, denoted $y_{1 i}$, and investigative categorisation, denoted $y_{2 i}$.

For the analysis of merger decisions, the outcome variable is binary.

$$
y_{1 i}= \begin{cases}1 & \text { If merger is prohibited or conditionally approved } \\ 0 & \text { If merger is approved without conditions. }\end{cases}
$$

Given the binary outcome variable, the analysis follows the Linear Probability Model (LPM) framework.

$$
E\left[y_{1 i} \mid X_{i}\right]=p_{i}=\operatorname{prob}\left(y_{1 i}=1 \mid X_{i}\right)=X_{i} \beta
$$

In equation (2), $X_{i}$ is a vector of control variables describing the merger, while $\beta$ is a vector of parameters to be estimated. There are two disadvantages associated with the LPM. The first is that underlying model is heteroskedastic, as the variance of the error term is binomial, and depends on the variables in the model. This problem is easily corrected through heteroscedasticity-consistent estimation of the regression. The second is that the predictions from the model could lie outside the unit interval, such that the model predicts probabilities that do not strictly follow 
the rule of probabilities. However, as predicted probabilities are not the focus of the anlayis, this last concern can be ignored. The LPM framework also has a few advantages. The first is that the estimated parameters are the marginal effects, which eliminates the need to calculate non-linear marginal effects. The second is that quasi-separation in the data does not eliminate observations from the LPM. For our purposes, it is important to note that public interest concerns were not raised for any of the approved mergers. If public interest concerns were included and the analysis followed either probit or logit, mergers in which the public interest was raised as a concern would not have been included in the analysis, as they would have perfectly predicted the outcome of either prohibition or conditional approval. For that reason, the LPM, which calculates an average effect, is superior, since it can use all of the data in the sample. Finally, due to the fact that the data was sampled, sample weights were included in the analysis, such that the estimates match the population.

For the analysis of the investigative process, the outcome variable takes on three values that are rankable.

$$
y_{2 i}= \begin{cases}1 & \text { Non-complex Merger } \\ 2 & \text { Complex Merger } \\ 3 & \text { Very Complex Merger }\end{cases}
$$

Due to the ordinal and discrete nature of the dependent variable, an ordered logit model was estimated for this outcome. Defining an index function over the independent variables, $X_{i} \gamma$, cutoff values, $\kappa_{j}$, and an error term, $u_{i}$, equation (3) can be described more precisely.

$$
y_{2 i}=\left\{\begin{array}{lc}
1 & \text { If } \kappa_{0}-X_{i} \gamma<u_{i} \leq \kappa_{1}-X_{i} \gamma \\
2 & \text { If } \kappa_{1}-X_{i} \gamma<u_{i} \leq \kappa_{2}-X_{i} \gamma \\
3 & \text { If } \kappa_{2}-X_{i} \gamma<u_{i} \leq \kappa_{4}-X_{i} \gamma
\end{array}\right.
$$


Furthermore, setting $\kappa_{0}=-\infty, \kappa_{4}=\infty$, the remaining $\kappa_{j}$ values and $\gamma$ can be estimated via maximum likelihood, which requires various likelihood components, starting with the probabilities.

$$
\begin{aligned}
\operatorname{prob}\left(y_{2 i}=j \mid X_{i}\right)=p_{i j} & =\operatorname{prob}\left(\kappa_{j-1}-X_{i} \gamma<u_{i} \leq \kappa_{j}-X_{i} \gamma\right) \\
& =\Lambda\left(\kappa_{j}-X_{i} \gamma\right)-\Lambda\left(\kappa_{j-1}-X_{i} \gamma\right)
\end{aligned}
$$

In equation (5), $\Lambda$ represents the logistic distribution function: $\exp (\nu) /(1+\exp (\nu))$. A normal distribution function could also be assumed, but the difference in the marginal effects would be minimal. From this probability, and the preceding assumptions, the likelihood function can be constructed.

$$
\mathcal{L}\left(\gamma, \kappa \mid y_{2}, X\right)=\prod_{i=1}^{N} \prod_{j=1}^{3}\left[\Lambda\left(\kappa_{j}-X_{i} \gamma\right)-\Lambda\left(\kappa_{j-1}-X_{i} \gamma\right)\right]^{y_{2 i j}}
$$

In equation (6), $y_{2 i j}=1$ if $y_{2 i}=j$, where $j=\{1,2,3\}$. As with the LPM, the ordered logit regressions and marginal effects, discussed below, are weighted to match the population of mergers.

Unfortunately, the estimated coefficients from the ordered logit model do not provide much useful information, and, therefore, marginal effects for each investigative level were, instead, estimated, at the mean of the data, and standard errors of those marginal effects were calculated via the Delta method. Given the probabilities defined in equation (5), marginal effects can be uncovered via either calculus, in the case of continuous independent variables, or via differencing, in the case of discrete independent variables. For a continuous variable $x_{i k} \in X_{i}$, the marginal effect on $p_{i j}$ can be estimated from the following equation.

$$
\frac{\partial p_{i j}}{\partial x_{i k}}=-\gamma_{k}\left[\Lambda^{\prime}\left(\kappa_{j}-X_{i} \gamma\right)-\Lambda^{\prime}\left(\kappa_{j-1}-X_{i} \gamma\right)\right]
$$

For a discrete variable $x_{i \ell} \in X_{i}$, the marginal effect on $p_{i j}$ can also be estimated.

$$
\frac{\Delta p_{i j}}{\Delta x_{i \ell}}=\left(p_{i j} \mid x_{i \ell}=1\right)-\left(p_{i j} \mid x_{i \ell}=0\right)
$$


Importantly, as there are three different outcomes in the ordered probability model, there are three different sets of marginal effects addressing the separate probabilities of any merger falling into any of the three categories. As can be seen in the tables of marginal effects for the ordinal models, the sum of the marginal effects is zero, as it should be: since all of the probabilities sum to a constant, in this case one, the derivative of those probabilities with respect to any variable will sum to zero.

\section{Results}

Two sets of empirical analyses were considered, one set based on linear probability models and another based on an ordered logit model. Each of these analyses provide information related to the determinants of particular decisions; assuming weak exogeneity of the explanatory variables, the results can be interpreted to be causal. The plausibility of that assumption is also discussed. The results from the analysis are located in Tables 3, 4 and 5. Each of these analyses are discussed, in turn, below.

5.1. Linear Probability Model I. The first analysis focuses on fiscal year differences in decisions, which provides some evidence about the consistency of merger decisions through time, as well as the relationship between investigation phase and decisions. The results, although useful, are not likely to be causal, since there could be differences in the actual mergers in any particular year, while investigation phases could also be related to various features of each merger.

The model is estimated for all mergers in the database, as well as for vertical, horizontal and conglomerate mergers, separately. The columns in Table 3 represent results for the respective analyses. Unfortunately, there are very few conglomerate mergers in the dataset, such that the determinants of conglomerate merger decisions are imprecisely estimated. However, for both vertical and horizontal mergers, as well as for all mergers, sample sizes are much larger. Therefore, the following discussion will focus on those regression results.

Table 3 about here 
For vertical mergers, horizontal mergers and all mergers, increased market shares are associated with an increase in the probability that a merger is not approved; for each percentage increase in the market share of the combined merger, the probability of either conditional approval or prohibition rises by between $0.6 \%$ and $0.8 \%$. Furthermore, for all mergers, if the investigation is recorded to be complex, the probability of unconditional approval decreases by nearly 11\%; for vertical mergers, the decrease is closer to $17 \%$. Very complex mergers are even less likely to be approved than complex mergers. For all mergers, the probability of either conditional approval or prohibition is $22 \%$ higher for very complex mergers. For vertical mergers, the estimate is $26.5 \%$, and for horizontal mergers, $19.7 \%$.

More worrying, however, from the point of view of consistency, are the estimated fiscal year influences on merger decisions. In the analysis, FY2002 is the base year, and, with the exception of conglomerate mergers, mergers are less likely to be unconditionally approved in at least two of the fiscal years between 2003 and 2009. ${ }^{15}$ Therefore, the Commission does appear to be acting inconsistently over the time period, at least with respect to the limited number of variables included in the intial analysis. Although the Commission appears to behave inconsistently, a conclusion of this nature is premature, as there are at least two potential concerns that were not captured in this analysis, that could matter. The first is that it is not possible to control for merger applications that are either not notified or have been withdrawn; some parties may have decided that their merger would not be successful, and, therefore, withdrawn the merger application. The second is that there could be other factors that are more prevalent in certain years or certain types of mergers that are more common in some years than others. Unfortunately, the first concern cannot be dealt with in this analysis, and, therefore, it will remain as a caveat for all subsequent analyses. The second concern, however, to which we turn, below, can be addressed, at least in part.

${ }^{15} \mathrm{~A}$ formal test that fiscal year effects are simultaneously zero is rejected for all mergers $\left(F_{7,299}=\right.$ 2.37, $p=0.02)$, vertical mergers $\left(F_{6,83}=3.36, p=0.01\right)$ and horizontal mergers $\left(F_{7,209}=2.30\right.$, $p=0.03$. 
5.2. Ordered Logit Analysis of Investigation Phase. In the preceding analysis, investigation complexity was found to be an important determinant of merger decisions at the Commission over the decade of the 2000s, while differences in decisions were observed across the fiscal years. However, the complexity of the investigation is an indicator of the investigation process, through which, the Commission considers mergers. For that reason, merger complexity was analysed separately, in an effort to uncover whether market contestibility factors were related to the Commission's complexity ranking. Marginal effects from the analysis are presented in Table 4.

\section{Table 4 about here}

The analysis suggests that combined market shares, the unavailbility of market share information, potential coordinated effects, potential import competition, market dynamics and growth, a history of collusion and barriers to entry are all important determinants of the Commission's complexity classification. Specifically, mergers are more likely to be classified higher on the complexity scale if combined market shares are larger, there are concerns over coordinated effects, if there is potential import-based competition to the merger, if markets are more dynamic, and if there is a history of collusion in the merging market. On the other hand, higher barriers to entry and a lack of information on the combined market share are associated with higher complexity ranks. For the most part, these results are consistent with our intuition about market contestibility, with the exception of the effect of import competition. In order to understand this counterintuitive result, it is important to recall the definition of complexity discussed in Section 3.1. More complex mergers are likely to undergo a more stringent analysis, such that information related to import competition is more likely to be recorded in more complex mergers than in non-complex mergers. In other words, it is quite plausible the cause and effect is not correctly captured, at least with respect to import competition.

To be more precise regarding the relationships, mergers with low barriers to entry are $10 \%$ more likely to be classified as non-complex, $6.5 \%$ less likely to be 
classified as complex and $3.9 \%$ less likely to be classified as very complex. Similarly, if market share data is missing, that merger is $17.2 \%$ more likely to be classified as non-complex, but $10.9 \%$ and $6.4 \%$ less likely to be classified as complex or very complex, respectively. Possibly, this result is driven by the commission not conducting detailed market share research on mergers it deems as non-complex. On the other hand, if there is a history of collusion in the market, a merger is $16 \%$ less likely to be classified as non-complex, but $10 \%$ and $6 \%$ more likely to be classified, respectively, as either complex or very complex. For import competition, mergers are $11.1 \%$ less likely to be deemed non-complex, but $7 \%$ more likely to be deemed complex and $4.1 \%$ more likely to be labelled as very complex. In addition, if there are significant dynamics in the merging market, a merger is $13.2 \%$ less likely to be labelled as non-complex, but $8.3 \%$ more likely to be deemed as complex and $4.9 \%$ more likely to listed as very complex. Finally, if there is a concern over coordinated effects in the market, the estimates are $24.5 \%$ less likely to be non-complex, $15.4 \%$ more likely to be complex and $9.1 \%$ more likely to be very complex.

5.3. Linear Probability Model II. In the preceding analyses, merger complexity was found to impact merger approval at the Commission between FY2002FY2009, while approvals appeared to be inconsistently determined through time. Furthermore, merger complexity was found to be associated with various measures of market contestibility. Therefore, in a follow-up analysis, a reduced form linear probability model, in which the market contestibility variables replace merger complexity as determinants of merger decisions, are considered. Those results are reported in Table 5, and are reported in the same way as the results in Table 3.

\section{Table 5 about here}

As with the initial analysis, the determinants of conglomerate merger decisions are generally not precisely estimated, due to small sample sizes, but are presented for completeness. In this analysis, low barriers to entry are associated with a reduced probability that the merger is not approved; the estimates range between $17 \%$ and $28 \%$. Similarly, if there is countervailing buyer power within the market, 
the probability that the merger is not approved falls by between $20 \%$ and $23 \%$. Dynamic markets are also viewed more favourably by the Commission; mergers in dynamic markets are between $4 \%$ and $5.5 \%$ more likely to be unconditionally approved, although the vertical merger estimate is imprecisely estimated. On the other hand, if the Commission is concerned with the potential for coordinated effects between firms, the probability that the merger is not approved lies between $24 \%$ and $60 \%$ higher than for mergers in which coordinated effects are not a concern.

In addition to the previously discussed market contestibility factors, the model also included each of the fiscal years to examine the consistency of Commission behavour through time. As previosuly discussed, it is possible that the observed inconsistency in the behaviour was being driven by differences in the types of mergers that were sampled for the anlaysis. Formal tests of joint significance across each of the subsamples suggests that the inclusion of market contestibility measures alleviates the original concerns over dynamic inconsistency in merger decisions at the Commission. ${ }^{16}$

Finally, according to the Act, interested parties are allowed to provide arguments against a merger that are based upon the public interest. In the sample data, public interest concerns were raised only in mergers that were either prohibited or conditionally approved. The resulting quasi-separation in the data raises difficulties with respect to both logit and probit models, although does not raise any difficulties in terms of the linear probability model, which partly justifies the focus on linear probability models. One potentially unsurprising result of that quasi-separation is that public interest concerns are found to be an important determinant of Commission disapproval. However, as Lewis (2002) notes, public interest concerns were not used to block mergers, although those concerns often resulted in some conditions being applied to those mergers. Constantinou's (2012) analysis suggests that some

\footnotetext{
${ }^{16}$ For all mergers, the test statistic was marginally significant, $F_{7,292}=1.57, p=0.14$; however, for vertical mergers, $F_{6,76}=1.19, p=0.32$, horizontal mergers, $F_{7,202}=1.39, p=0.21$, and conglomerate mergers, $F_{7,43}=0.11, p=0.99$, joint significance of the fiscal year effects is not accepted.
} 
of these conditions, at least with respect to the merger between Momentum and Metropolitan, were viewed as inefficient by stock market participants.

\section{Discussion And Conclusion}

This research has examined the determinants of and the consistency with which the Competition Commission has evaluated merger transactions notified during the period from FY2002 to FY2009. Data was extracted from a population of 2277 mergers, and the analysis, undertaken in three parts, hinged upon linear probability models corrected for our sampling strategy, as well as ordered logit models of investigation complexity.

In line with economic theory, as well as the guidelines set out by the Act, the Commission pays very careful attention to variables that are directly tied to competition. The Commission views larger post-merger market shares as something to be avoided. Large post-merger market shares, unsurprisingly, have also featured as important determinants of merger approval in the rest of the international literature - Coate \& McChesney (1992), Weir (1992), Khemani \& Shapiro (1993), Bergman et al. (2005) and Avalos \& De Hoyos (2008) - and in the limited South African literature - Smith (2003). Complex and very complex mergers, which have not previously featured in the literature, are also viewed skeptically, being $18 \%$ and $25 \%$, respectively, more likely to be either conditionally approved or prohibited. However, complexity effects are found to depend on market contestibility.

Although the results initially suggested inconsistent behaviour through time; however, the introduction of market contestibility measures changes that view. When market contestibility variables are included in the analysis, year effects are found to be insignificant, suggesting that the initial observation of dynamic inconsistency at the Commission was an artefact of omitted variables bias. For the most part, the remainder of the results from the analysis confirm intuition. For example, coordinated effects in the market are treated more skeptically. On the other hand, minimal barriers to entry are associated with more contestibility within the market, 
and, therefore, the merger is less likely to be regarded as anti-competitive by the Commission. Similarly, mergers that occur in relatively more dynamic markets are more likely to be approved, as are mergers in markets in which there is countervailing buyer power. As expected, mergers in markets that are more competitive are generally viewed more positively, while mergers in markets that are likely to be less competitive are viewed more skeptically. These results, related to the underlying level of competition and determinants of competition, are similar to that found by Coate \& McChesney (1992), Weir (1992), Khemani \& Shapiro (1993), Bergman et al. (2005) and Avalos \& De Hoyos (2008).

Finally, the Commission takes seriously its responsibility to protect the public interest. When such interests are raised by parties concerned with the merger, the Commission takes notice. In this sample, if a stakeholder was concerned with potential negative impacts on the broader public, the Commission was much more likely to either place conditions on the merger or prohibit it completely. This result, however is not easily compared to the literature, since the public interest is not an explicit goal of competition policy in most countries. Weir (1992) finds that public interest concerns were not important determinants of MMC behaviour between 1974 and 1990. Similarly, Smith (2003) finds minimal evidence that the South African Competition Commission worried about public interest considerations before 2003, although Black Economic Empowerment considerations affect decisions in his subsample of large mergers. The majority of public interest analysis in the international literature, rather than focussing on an explicit goal, has considered the potential for political or national influence in the analysis. Along those lines, Coate \& McChesney (1992) find evidence of political pressure affecting merger decisions in the U.S., while Lindsay et al. (2003), Bergman et al. (2005) and Avalos $\&$ De Hoyos (2008) do not find evidence of the relevant authorities discriminating against foreign-based firms.

Our analysis is one of the few to examine competition policy in South Africa, having considered more recent and more detailed data than either Theron (2001), 
Smith (2003) or Roberts (2004). Similarly, it is one of the first to examine merger policy in a developing middle income country; the only other analysis we were able to find was for Mexico by Avalos \& De Hoyos (2008). Given the changes in the structure of industry in developing economies, driven in part by privatisation and a recent increase in international mergers, the analysis contributes to a rather small, but growing, literature on the enforcement of competition policy in developing economies.

Although the results support our intuition, a few caveats remain. Importantly, the estimation results may, instead of pointing to consistent behaviour at the Commission, point to consistent interpretation of the merger data, since a degree of subjectivity was necessary for the compilation of the dataset. Even though it is not possible to further examine our subjectivity, a recommendation to the Commission arises from the analysis. A more succinct data capturing process at the Commission would be beneficial. We would also note that it was not possible to control for the entire decision-making process, including the investigators and directors making recommendations or the discussions surrounding those recommendations. Although not necessarily relevant to our analysis, it would be interesting to see if a subgroup of investigators or other actors in the Commission were more or less likely to approve any particular merger. Finally, the analysis assumes that the target population, and, therefore, the sample population, is representative of mergers. Given that Commission behaviour is likely to influence the applications received, as was found by Seldeslachts et al. (2009), the target population is not likely to be representative of all potential mergers during the time period. Therefore, our results are only relevant with respect to all notified mergers between April 2002 and March 2010.

This research only addresses the determinants and consistency of the Commission's decisions with respect to mergers; however, it paves the way for future research into the market's reaction to merger notifications. In particular, future research could investigate whether or not stock markets appropriately price the 
stocks of merging entities, analysing whether or not stock markets internalize the Commission's most likely decision, along the lines of the analyses performed by Aktas, de Brodt \& Roll (2004), Duso et al. (2007) and Ivaldi \& Verboven (2005). Furthermore, research into the post-merger performance of merged entities and the markets in which these entities operate would provide evidence related to the appropriateness of the principles contained in the Act.

\section{REFERENCES}

Adhikari, R. \& Knight-John, M. (2004), 'What type of competition policy and law should a developing country have?', South Asia Economic Journal 5(1), 1-25.

Aktas, N., de Brodt, E. \& Roll, R. (2004), 'Market responses to European regulation of business combinations', Journal of Financial and Quantitative Analysis 39(4), 731-757.

Avalos, M. \& De Hoyos, R. E. (2008), 'An empirical analysis of Mexican merger policy', Review of Industrial Organization 32, 113-130.

Bergman, M. A., Jakobsson, M. \& Razo, C. (2005), 'An econometric analysis of the European Commission's merger decisions', International Journal of Industrial Organization 23, 717737.

Coate, M. B. (2005), 'Empirical analysis of merger enforcement under the 1992 merger guidelines', Review of Industrial Organization 27, 219-301.

Coate, M. B. \& McChesney, F. S. (1992), 'Empirical evidence on FTC enforcement of the merger guidelines', Economic Inquiry 30, 277-293.

Competition Commission and Competition Tribunal (2009), 'Unleashing rivalry: Ten years of enforcement by the South African Competition Authorities'.

Constantinou, A. (2012), Ex-post review of the merger between Metropolitan and Momentum: An event study, Master's thesis, University of Pretoria.

Davies, S. W., Driffield, N. L. \& Clarke, R. (1999), 'Monopoly in the UK: What determines whether the MMC finds against the investigated firms', The Journal of Industrial Economics 47(3), 263-283.

Duso, T., Neven, D. J. \& Röller, L.-H. (2007), 'The political economy of European merger control: evidence using stock market data', Journal of Law and Economics 50(3), 455-489.

Geweke, J., Meese, R. \& Dent, W. (1983), 'Comparing alternative tests of causality in temporal systems: Analytical results and experimental evidence', Journal of Econometrics 21, 161194. 
Ghosal, V. \& Gallo, J. (2001), 'The cyclical behavior of the Department of Justice's antitrust enforcement activity', International Journal of Industrial Organization 19, 27-54.

Granger, C. (1969), 'Investigating causal relationships by econometric models and cross-spectral methods', Econometrica 37, 424-438.

Grimbeek, S. (2011), An econometric analysis of the South African Competition Commission's merger decisions, Master's thesis, University of Pretoria.

Grimbeek, S., Koch, S. F. \& Grimbeek, R. J. (2012), 'The consistency of merger decisions in a developing country: The South African Competition Commission', Economic Research Southern Africa Working Paper Series No. 288.

Ivaldi, M. \& Verboven, F. (2005), 'Quanitifying the effects from horizontal mergers in European competition policy', International Journal of Industrial Organization 23, 669-691.

Khemani, R. S. \& Shapiro, D. M. (1993), 'An empirical analysis of Canadian merger policy', Journal of Industrial Economics 41, 161-177.

Kovacic, W. E. \& Shapiro, C. (2000), 'Antitrust policy: a century of legal thinking', Journal of Economic Perspectives 14(1), 43-60.

Lewis, D. (2002), 'The role of public interest in merger evaluation'. Paper presented to the International Competition Network, Naples.

URL: www.comptrib.co.za/publications/speeches

Lindsay, A., Lecchi, E. \& Williams, G. (2003), 'Econometrics study into European merger decisions since 2000', European Competition Law Review 24, 673-682.

Neven, D. \& Zenger, H. (2008), 'Ex post evaluation of enforcement: a principal-agent perspective', De Economist 156(4), 477-490.

Nilssen, T. (1997), 'On the consistency of merger policy', The Journal of Industrial Economics 45(1), 89-100.

Posner, R. A. (1970), 'A statistical study of antitrust enforcement', Journal of Law and Economics 13(2), 365-419.

Reekie, W. D. (1999), 'The Competition Act, 1998: An economic perspective', South African Journal of Economics 67(2), 257-288.

Roberts, S. (2004), 'The role for competition policy in economic development: The South African experience', Development Southern Africa 21(1), 227-243.

Röller, L. H. \& Neven, D. (2002), Discrepencies between markets and regulators: An analysis of the first ten years of EU merger control, in 'The Pros and Cons of Merger Control', The Swedish Competition Authority, Stockholm.

Seldeslachts, J., Clougherty, J. A. \& Pita Barros, P. (2009), 'Settle for now but block for tomorrow: the deterrence effects of merger policy tools', Journal of Law and Economics 52(3), 607-634. 
Smith, P. D. (2003), Competition policy in South Africa: The impact and the role of the public interest, Master's thesis, St. Johns College, Oxford University.

Theron, N. (2001), 'The economics of competition policy: Merger analysis in South Africa', South African Journal of Economics 69(4), 614-658.

Weir, C. (1992), 'Monopolies and mergers commission, merger reports and the public interest: a probit analysis', Applied Economics 24, 27-34.

Weir, C. (1993), 'Merger policy and competition: an analysis of the Monopolies and Merger Commission's decisions', Applied Economics 25, 57-66.

TABle 1. Population and Sample

\begin{tabular}{|l|c|c|c|c|c|c|c|}
\hline Category & Type & $\begin{array}{c}\text { Target } \\
\text { Population } \\
\text { A }\end{array}$ & $\begin{array}{c}\text { Sample } \\
\text { Population } \\
\text { A }\end{array}$ & $\begin{array}{c}\text { Sample } \\
\text { A }\end{array}$ & $\begin{array}{c}\text { Target } \\
\text { Population } \\
\text { P+CA }\end{array}$ & $\begin{array}{c}\text { Sample } \\
\text { Population } \\
\text { P+CA }\end{array}$ & $\begin{array}{c}\text { Sample } \\
\text { P+CA }\end{array}$ \\
\hline Non-complex & Small & 21 & 18 & 13 & 0 & 0 & 0 \\
Non-complex & Intermediate & 1406 & 1406 & 83 & 3 & 2 & 2 \\
Complex & Large & 328 & 273 & 33 & 2 & 2 & 2 \\
Complex & Small & 11 & 11 & 8 & 2 & 1 & 1 \\
Complex & Intermediate & 247 & 238 & 27 & 9 & 9 & 8 \\
Very Complex & Large & 138 & 115 & 23 & 12 & 10 & 8 \\
Very Complex & Small & 7 & 6 & 7 & 5 & 5 & 5 \\
Very Complex & Large & 71 & 56 & 19 & 34 & 34 & 33 \\
\hline Total & & 48 & 42 & 16 & 24 & 24 & 22 \\
\hline
\end{tabular}

Target population represents the underlying population of mergers available for consideration.

Sample population represents the sample that was drawn from the population of mergers available. 
TABLe 2. Summary Statistics of Analysis Variables

\begin{tabular}{|c|c|c|c|}
\hline Variable & Short Definition & $\begin{array}{r}\text { Not Approved } \\
\text { Mean } \\
\text { (S.E.) }\end{array}$ & $\begin{array}{r}\text { Approved } \\
\text { Mean } \\
\text { (S.E.) }\end{array}$ \\
\hline M-Share & 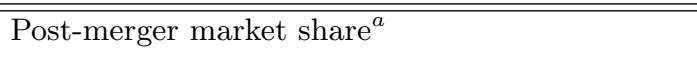 & $\begin{array}{r}48.824^{b} \\
(4.22)\end{array}$ & $\begin{array}{r}16.447 \\
(1.09)\end{array}$ \\
\hline M-Share $\geq 45 \%$ & Post-merger market share $\geq 45 \%^{a}$ & $\begin{array}{c}0.516^{b} \\
(0.08)\end{array}$ & $\begin{array}{r}0.042 \\
(0.01)\end{array}$ \\
\hline M-Share Miss & Market share not available & $\begin{array}{r}0.175 \\
(0.08)\end{array}$ & $\begin{array}{l}0.451^{c} \\
(0.05)\end{array}$ \\
\hline Large & Merger type large $=1$ & $\begin{array}{c}0.360^{d} \\
(0.08)\end{array}$ & $\begin{array}{r}0.191 \\
(0.03)\end{array}$ \\
\hline Small & Merger type small $=1$ & $\begin{array}{r}0.031 \\
(0.01)\end{array}$ & $\begin{array}{r}0.017 \\
(0.01)\end{array}$ \\
\hline Complex & Merger category complex $=1$ & $\begin{array}{l}0.401^{c} \\
(0.08)\end{array}$ & $\begin{array}{r}0.147 \\
(0.03)\end{array}$ \\
\hline Very Complex & Merger category very complex $=1$ & $\begin{array}{l}0.382^{b} \\
(0.07)\end{array}$ & $\begin{array}{r}0.042 \\
(0.01)\end{array}$ \\
\hline Horizontal & Horizontal merger $=1$ & $\begin{array}{r}0.818^{d} \\
(0.08)\end{array}$ & $\begin{array}{r}0.608 \\
(0.05)\end{array}$ \\
\hline Vertical & Vertical merger $=1$ & $\begin{array}{r}0.275 \\
(0.06)\end{array}$ & $\begin{array}{r}0.170 \\
(0.03)\end{array}$ \\
\hline Conglomerate & Conglomerate merger $=1$ & $\begin{array}{r}0.117 \\
(0.08)\end{array}$ & $\begin{array}{r}0.297^{d} \\
(0.04)\end{array}$ \\
\hline Import & Import competition constrains behaviour $=1$ & $\begin{array}{r}0.200 \\
(0.07)\end{array}$ & $\begin{array}{r}0.086 \\
(0.02)\end{array}$ \\
\hline Barriers & Low barriers to entry $=1$ & $\begin{array}{r}0.218 \\
(0.08)\end{array}$ & $\begin{array}{l}0.944^{b} \\
(0.02)\end{array}$ \\
\hline Collusion & History of collusion in market $=1$ & $\begin{array}{l}0.074^{b} \\
(0.02)\end{array}$ & $\begin{array}{r}0.009 \\
(0.01)\end{array}$ \\
\hline Countervailing & Countervailing buyer power in market $=1$ & $\begin{array}{r}0.587 \\
(0.08)\end{array}$ & $\begin{array}{l}0.984^{b} \\
(0.01)\end{array}$ \\
\hline Failing & One of merging parties is failing $=1$ & $\begin{array}{r}0.082 \\
(0.05)\end{array}$ & $\begin{array}{r}0.026 \\
(0.01)\end{array}$ \\
\hline Removal & Result in removal of effective competitor $=1$ & $\begin{array}{l}0.288^{b} \\
(0.06)\end{array}$ & $\begin{array}{c}0.004 \\
(0.00)\end{array}$ \\
\hline Coordinated & Potential post-merger coordinated effects $=1$ & $\begin{array}{l}0.281^{b} \\
(0.07)\end{array}$ & $\begin{array}{r}0.003 \\
(0.00)\end{array}$ \\
\hline Growth & Dynamics are integral feature of the market $=1$ & $\begin{array}{r}0.0436 \\
(0.08)\end{array}$ & $\begin{array}{r}0.540 \\
(0.05)\end{array}$ \\
\hline Public Interest & Public interest concerns $=1$ & $\begin{array}{r}0.431 \\
(0.09) \\
\end{array}$ & $\begin{array}{l}\mathrm{N} / \mathrm{A}^{e} \\
\mathrm{~N} / \mathrm{A}\end{array}$ \\
\hline
\end{tabular}

${ }^{a}$ Assumed to be $15 \%$ in case of missing data. ${ }^{b}$ - Significantly different at 0.001 .

${ }^{c}$ - Significantly different at $0.01 .^{d}$ - Significantly different at 0.05 .

${ }^{e}$ - Only occurs in unapproved cases.

Significance refers to the mean being significantly larger in that particular subsample. 
TABle 3. Parameter Estimates and Marginal Effects: LPM I

\begin{tabular}{|c|c|c|c|c|}
\hline VARIABLES & $\begin{array}{c}\text { All } \\
\text { Mergers }\end{array}$ & $\begin{array}{l}\text { Vertical } \\
\text { Mergers }\end{array}$ & $\begin{array}{l}\text { Horizontal } \\
\text { Mergers }\end{array}$ & $\begin{array}{c}\text { Conglomerate } \\
\text { Mergers }\end{array}$ \\
\hline Market Share & $\begin{array}{l}0.0067^{a} \\
(0.0015)\end{array}$ & $\begin{array}{r}0.0057^{a} \\
(0.0016)\end{array}$ & $\begin{array}{r}0.0081^{a} \\
(0.0018)\end{array}$ & $\begin{array}{l}-0.0038 \\
(0.0034)\end{array}$ \\
\hline Complex & $\begin{array}{l}0.1077^{c} \\
(0.0576)\end{array}$ & $\begin{array}{l}0.1671^{b} \\
(0.0821)\end{array}$ & $\begin{array}{l}0.0755 \\
(0.0629)\end{array}$ & $\begin{array}{l}0.1462 \\
(0.1268)\end{array}$ \\
\hline Very Complex & $\begin{array}{l}0.2202^{b} \\
(0.0872)\end{array}$ & $\begin{array}{l}0.2649^{b} \\
(0.1044)\end{array}$ & $\begin{array}{l}0.1968^{c} \\
(0.1047)\end{array}$ & $\begin{array}{l}-0.0829 \\
(0.1140)\end{array}$ \\
\hline FY2003 & $\begin{array}{l}0.0944 \\
(0.0728)\end{array}$ & $\begin{array}{r}0.3525^{a} \\
(0.1149)\end{array}$ & $\begin{array}{l}0.0390 \\
(0.0903)\end{array}$ & $\begin{array}{l}0.0284 \\
(0.0354)\end{array}$ \\
\hline FY2004 & $\begin{array}{r}0.2117^{a} \\
(0.0724)\end{array}$ & $\begin{array}{r}0.4118^{a} \\
(0.1239)\end{array}$ & $\begin{array}{l}0.2041^{b} \\
(0.0850)\end{array}$ & $\begin{array}{l}0.0296 \\
(0.0338)\end{array}$ \\
\hline FY2005 & $\begin{array}{l}0.1512^{b} \\
(0.0751)\end{array}$ & $\begin{array}{r}0.4099^{a} \\
(0.1294)\end{array}$ & $\begin{array}{l}0.1065 \\
(0.1053)\end{array}$ & $\begin{array}{l}0.0331 \\
(0.0347)\end{array}$ \\
\hline FY2006 & $\begin{array}{r}0.1259^{d} \\
(0.0779)\end{array}$ & $\begin{array}{c}\mathrm{N} / \mathrm{A}^{e} \\
-\end{array}$ & $\begin{array}{l}0.0794 \\
(0.0919)\end{array}$ & $\begin{array}{l}0.0296 \\
(0.0338)\end{array}$ \\
\hline FY2007 & $\begin{array}{l}0.1303^{c} \\
(0.0675)\end{array}$ & $\begin{array}{r}0.3610^{a} \\
(0.0919)\end{array}$ & $\begin{array}{l}0.0808 \\
(0.0785)\end{array}$ & $\begin{array}{l}0.0286 \\
(0.0337)\end{array}$ \\
\hline FY2008 & $\begin{array}{r}0.2381^{a} \\
(0.0856)\end{array}$ & $\begin{array}{c}0.5846^{a} \\
(0.1722)\end{array}$ & $\begin{array}{l}0.1884^{b} \\
(0.0833)\end{array}$ & $\begin{array}{l}0.1552 \\
(0.1303)\end{array}$ \\
\hline FY2009 & $\begin{array}{l}0.2143^{c} \\
(0.1167)\end{array}$ & $\begin{array}{l}0.3343^{a} \\
(0.1024)\end{array}$ & $\begin{array}{l}0.0897 \\
(0.1185)\end{array}$ & $\begin{array}{l}0.3767 \\
(0.2922)\end{array}$ \\
\hline Constant & $\begin{array}{c}-0.2157^{a} \\
(0.0634)\end{array}$ & $\begin{array}{c}-0.4295^{a} \\
(0.1032)\end{array}$ & $\begin{array}{c}-0.1787^{b} \\
(0.0705)\end{array}$ & $\begin{array}{l}0.0277 \\
(0.0551)\end{array}$ \\
\hline Observations & 310 & 93 & 220 & 58 \\
\hline$R^{2}$ & 0.3453 & 0.4070 & 0.4244 & 0.2378 \\
\hline
\end{tabular}


TABLE 4. Ordered Logit Marginal Effects: Investigation Phase

\begin{tabular}{|c|c|c|c|}
\hline VARIABLES & $\begin{array}{c}\text { Phase } \\
\text { Non-Complex }\end{array}$ & $\begin{array}{c}\text { Phase } \\
\text { Complex } \\
\end{array}$ & $\begin{array}{c}\text { Phase } \\
\text { Very Complex }\end{array}$ \\
\hline Market Share & $\begin{array}{c}-0.0045^{a} \\
(0.0017)\end{array}$ & $\begin{array}{r}0.0028^{a} \\
(0.0011)\end{array}$ & $\begin{array}{r}0.0017^{a} \\
(0.0006)\end{array}$ \\
\hline Share Missing & $\begin{array}{r}0.1724^{a} \\
(0.0423)\end{array}$ & $\begin{array}{c}-0.1086^{a} \\
(0.0273)\end{array}$ & $\begin{array}{c}-0.0638^{a} \\
(0.0177)\end{array}$ \\
\hline Coordinated & $\begin{array}{c}-0.2447^{b} \\
(0.0913)\end{array}$ & $\begin{array}{l}0.1542^{b} \\
(0.0622)\end{array}$ & $\begin{array}{r}0.0905^{a} \\
(0.0316)\end{array}$ \\
\hline Import & $\begin{array}{c}-0.1112^{b} \\
(0.0561)\end{array}$ & $\begin{array}{l}0.0701^{b} \\
(0.0355)\end{array}$ & $\begin{array}{l}0.0411^{c} \\
(0.0215)\end{array}$ \\
\hline Growth & $\begin{array}{c}-0.1324^{a} \\
(0.0378)\end{array}$ & $\begin{array}{r}0.0834^{a} \\
(0.0246)\end{array}$ & $\begin{array}{r}0.0490^{a} \\
(0.0151)\end{array}$ \\
\hline Collusion & $\begin{array}{c}-0.1596^{d} \\
(0.1037)\end{array}$ & $\begin{array}{c}0.1006^{d} \\
(0.0658)\end{array}$ & $\begin{array}{c}0.0591^{d} \\
(0.0390)\end{array}$ \\
\hline Barriers & $\begin{array}{c}0.1044^{d} \\
(0.0687)\end{array}$ & $\begin{array}{c}-0.0657^{d} \\
(0.0426)\end{array}$ & $\begin{array}{c}-0.0386^{d} \\
(0.0267)\end{array}$ \\
\hline Countervailing & $\begin{array}{l}0.0327 \\
(0.0622)\end{array}$ & $\begin{array}{r}-0.0206 \\
(0.0394)\end{array}$ & $\begin{array}{r}-0.0121 \\
(0.0229)\end{array}$ \\
\hline Public Interest & $\begin{array}{l}0.0038 \\
(0.0690)\end{array}$ & $\begin{array}{l}-0.0024 \\
(0.0435)\end{array}$ & $\begin{array}{l}-0.0014 \\
(0.0256)\end{array}$ \\
\hline Failing & $\begin{array}{l}0.0608 \\
(0.0769)\end{array}$ & $\begin{array}{l}-0.0383 \\
(0.0486)\end{array}$ & $\begin{array}{l}0.0897 \\
(0.0285)\end{array}$ \\
\hline Removal & $\begin{array}{l}-0.0865 \\
(0.1004)\end{array}$ & $\begin{array}{l}0.0545 \\
(0.0645)\end{array}$ & $\begin{array}{l}0.0320 \\
(0.0362)\end{array}$ \\
\hline $\begin{array}{l}\text { Observations } \\
\ln \mathcal{L}^{e}\end{array}$ & $\begin{array}{c}310 \\
-0.4765\end{array}$ & $\begin{array}{c}310 \\
-0.4765\end{array}$ & $\begin{array}{c}310 \\
-0.4765\end{array}$ \\
\hline
\end{tabular}


TABLE 5. Parameter Estimates and Marginal Effects: LPM II

\begin{tabular}{|c|c|c|c|c|}
\hline VARIABLES & $\begin{array}{c}\text { All } \\
\text { Mergers }\end{array}$ & $\begin{array}{l}\text { Vertical } \\
\text { Mergers }\end{array}$ & $\begin{array}{c}\text { Horizontal } \\
\text { Mergers }\end{array}$ & $\begin{array}{c}\text { Conglomerate } \\
\text { Mergers }\end{array}$ \\
\hline Market Share & $\begin{array}{c}0.0023^{a} \\
(0.0007)\end{array}$ & $\begin{array}{l}0.0014 \\
(0.0010)\end{array}$ & $\begin{array}{c}0.0025^{a} \\
(0.0009)\end{array}$ & $\begin{array}{l}0.0001 \\
(0.0002)\end{array}$ \\
\hline Import & $\begin{array}{l}0.0403 \\
(0.0440)\end{array}$ & $\begin{array}{l}0.0724 \\
(0.0811)\end{array}$ & $\begin{array}{l}0.0865^{c} \\
(0.0516)\end{array}$ & $\begin{array}{l}-0.0037 \\
(0.0093)\end{array}$ \\
\hline Barriers & $\begin{array}{c}-0.2097^{a} \\
(0.0680)\end{array}$ & $\begin{array}{c}-0.1655^{b} \\
(0.0740)\end{array}$ & $\begin{array}{c}-0.2766^{a} \\
(0.0917)\end{array}$ & $\begin{array}{l}0.0151 \\
(0.0211)\end{array}$ \\
\hline Collusion & $\begin{array}{l}0.0515 \\
(0.0735)\end{array}$ & $\begin{array}{l}0.0286 \\
(0.0651)\end{array}$ & $\begin{array}{l}0.1400 \\
(0.0971)\end{array}$ & $\begin{array}{c}\mathrm{N} / \mathrm{A}^{e} \\
-\end{array}$ \\
\hline Countervailing & $\begin{array}{c}-0.2017^{a} \\
(0.0691)\end{array}$ & $\begin{array}{c}-0.2245^{b} \\
(0.0949)\end{array}$ & $\begin{array}{c}-0.2293^{b} \\
(0.0915)\end{array}$ & $\begin{array}{l}0.0091 \\
(0.0148)\end{array}$ \\
\hline Failing & $\begin{array}{l}0.0094 \\
(0.0444)\end{array}$ & $\begin{array}{l}-0.0867 \\
(0.2005)\end{array}$ & $\begin{array}{l}-0.0037 \\
(0.0512)\end{array}$ & $\begin{array}{c}-0.0213 \\
(0.0283)\end{array}$ \\
\hline Removal & $\begin{array}{l}0.1105 \\
(0.0966)\end{array}$ & $\begin{array}{l}0.0159 \\
(0.1129)\end{array}$ & $\begin{array}{l}0.0717 \\
(0.0917)\end{array}$ & $\begin{array}{c}\mathrm{N} / \mathrm{A}^{e} \\
-\end{array}$ \\
\hline Coordinated & $\begin{array}{l}0.3312^{a} \\
(0.1110)\end{array}$ & $\begin{array}{c}0.6032^{a} \\
(0.1138)\end{array}$ & $\begin{array}{l}0.2412^{b} \\
(0.1210)\end{array}$ & $\begin{array}{c}\mathrm{N} / \mathrm{A}^{e} \\
-\end{array}$ \\
\hline Growth & $\begin{array}{c}-0.0406^{c} \\
(0.0211)\end{array}$ & $\begin{array}{l}-0.0555 \\
(0.0603)\end{array}$ & $\begin{array}{c}-0.0549^{b} \\
(0.0255)\end{array}$ & $\begin{array}{l}-0.0229 \\
(0.0307)\end{array}$ \\
\hline Public Interest & $\begin{array}{l}0.6371^{a} \\
(0.0878)\end{array}$ & $\begin{array}{l}0.5810^{a} \\
(0.1144)\end{array}$ & $\begin{array}{c}0.5149^{a} \\
(0.0883)\end{array}$ & $\begin{array}{c}0.9701^{a} \\
(0.0375)\end{array}$ \\
\hline FY2003 & $\begin{array}{l}0.0266 \\
(0.0525)\end{array}$ & $\begin{array}{l}0.0539 \\
(0.0989)\end{array}$ & $\begin{array}{l}0.0292 \\
(0.0612)\end{array}$ & $\begin{array}{c}-0.0054 \\
(0.0078)\end{array}$ \\
\hline FY2004 & $\begin{array}{l}0.0628 \\
(0.0507)\end{array}$ & $\begin{array}{l}0.1385^{b} \\
(0.0638)\end{array}$ & $\begin{array}{l}0.0754 \\
(0.0613)\end{array}$ & $\begin{array}{r}-0.0095 \\
(0.0138)\end{array}$ \\
\hline FY2005 & $\begin{array}{c}-0.0172 \\
(0.0495)\end{array}$ & $\begin{array}{l}0.0043 \\
(0.0831)\end{array}$ & $\begin{array}{r}-0.0472 \\
(0.0624)\end{array}$ & $\begin{array}{l}-0.0064 \\
(0.0092)\end{array}$ \\
\hline FY2006 & $\begin{array}{l}0.0113 \\
(0.0448)\end{array}$ & $\begin{array}{c}\mathrm{N} / \mathrm{A}^{e} \\
-\end{array}$ & $\begin{array}{l}0.0016 \\
(0.0505)\end{array}$ & $\begin{array}{r}-0.0210 \\
(0.0281)\end{array}$ \\
\hline FY2007 & $\begin{array}{l}0.0164 \\
(0.0469)\end{array}$ & $\begin{array}{l}0.0675 \\
(0.0839)\end{array}$ & $\begin{array}{c}-0.0014 \\
(0.0555)\end{array}$ & $\begin{array}{c}-0.0174 \\
(0.0239)\end{array}$ \\
\hline FY2008 & $\begin{array}{l}0.0927 \\
(0.0662)\end{array}$ & $\begin{array}{l}0.0448 \\
(0.0905)\end{array}$ & $\begin{array}{l}0.0556 \\
(0.0579)\end{array}$ & $\begin{array}{l}0.0986 \\
(0.1173)\end{array}$ \\
\hline FY2009 & $\begin{array}{l}0.0559 \\
(0.0543)\end{array}$ & $\begin{array}{l}0.0437 \\
(0.0675)\end{array}$ & $\begin{array}{l}0.0395 \\
(0.0663)\end{array}$ & $\begin{array}{l}0.0022 \\
(0.0046)\end{array}$ \\
\hline Constant & $\begin{array}{c}0.3771^{a} \\
(0.1001)\end{array}$ & $\begin{array}{c}0.3339^{b} \\
(0.1592)\end{array}$ & $\begin{array}{c}0.4832^{a} \\
(0.1133)\end{array}$ & $\begin{array}{r}-0.0039 \\
(0.0126)\end{array}$ \\
\hline $\begin{array}{l}\text { Observations } \\
R^{2}\end{array}$ & $\begin{array}{c}310 \\
0.7293\end{array}$ & $\begin{array}{c}93 \\
0.7772\end{array}$ & $\begin{array}{c}220 \\
0.7752\end{array}$ & $\begin{array}{c}58 \\
0.6845\end{array}$ \\
\hline
\end{tabular}

